\title{
UTJECAJ EKSCENTRICITETA NA NOSIVOST PRIKLJUČKA ČELIČNIH REŠETKI
}

\author{
Sanja Junušić \\ Sveučilište J. J. Strossmayera u Osijeku, Građevinski fakultet Osijek, student \\ Jasmina Topić \\ Sveučilište J. J. Strossmayera u Osijeku, Građevinski fakultet Osijek, student \\ Aleksandar Jurić \\ Sveučilište J. J. Strossmayera u Osijeku, Građevinski fakultet Osijek, doc.dr.sc.
}

Sažetak: U radu se analizira utjecaj ekscentriciteta na nosivost priključka ravninskih čeličnih grednih rešetkastih nosača. Numerička analiza je provedena na konkretnom ravninskom rešetkastom nosaču s unaprijed odabranim dimenzijama nosača, a pretpostavljena je potpuna upetost štapova ispune u pojaseve. Kombinacija opterećenja usvojena je kao zbroj vlastite težine i pokretnog opterećenja, koncentriranih u čvorovima gornjeg pojasa. Ekscentriciteti su zadavani kao postotak visine presjeka pojasa, a zadavani su u gornjem pojasu, donjem pojasu te u oba pojasa. Za izabrane varijacije ekscentriciteta praćena je nosivost karakterističnog priključka gredne rešetke u čvoru najveće vlačne i tlačne sile, odnosno priključka prvog polja. Praćena je promjena nosivosti priključka zavisno od ekscentriciteta nastalog preklapanjem štapova, te ekscentriciteta nastalog razdvajanjem štapova, a rezultati su prikazani bezdimenzionalnim dijagramima i uspoređivani s vrijednostima dobivenim po euronormama.

Ključne riječi: rešetka, ekscentricitet, priključak, proračun nosivosti

\section{THE INFLUENCE OF EXCENTRICITY ON BEARING OF JOINT IN STEEL STRUCTURES}

\begin{abstract}
The paper analyses the influence of eccentricity on the bearing capacity of a connection of an in plane steel truss girder. The numerical analysis is conducted on an in plane truss girder with specific dimensions of elements and full rigid connection of inner elements with upper and lower band. The design load combination is consisted of self weight and live load as concentrated forces applied in of the upper band. The eccentricity is applied in the upper, lower band and in both upper and lower band as a percentage of the height of the upper band section. For the different selected eccentricities the bearing capacity of a connection of a truss in the joint with the biggest tensile and compressive force, which is in the first panel, is observed. The change in bearing capacity in connection to the eccentricity caused by the overlap and separation of elements is measured and compared to euro codes with no dimensional diagrams.
\end{abstract}

Key words: truss, eccentricity, connection, design procedure 


\section{Uvod}

Spajanjem gornjih i donjih pojasnih štapova sa štapovima ispune dolazi do odstupanja od centričnog spajanja, što rezultira pojavom ekscentriciteta. Istovremeno, dolazi do promjene unutarnjih sila u štapovima rešetke te do pojave dodatnih, sekundarnih naprezanja. Ako se ekscentricitet nalazi unutar propisanih granica $-0,55 \cdot h_{0} \leq e \leq 0,25 \cdot h_{0}$, pri čemu je $h_{0}$ visina čeličnog profila štapa pojasa, ta naprezanja možemo u proračunu zanemariti.

Promjena nosivosti priključaka čeličnih rešetki zavisno od ekscentriciteta definirana je euronormama [1] i literaturom [2] i [3], a analizirana u radovima nekih autora [4], [5] i [6]. U ovom radu analizirana je pomoću pripadnih izraza iz euronormi te pomoću jednog od, u inženjerskoj praksi uobičajenog programskog paketa [7]. Proračunata rešetkasta konstrukcija djelomično je preuzeta iz [4] i izvedena iz šupljih kvadratnih profila kvalitete čelika S235. Ekscentriciteti su zadavani kao postotak visine pojasnog štapa, gdje je negativni ekscentricitet nastao razmakom između štapova, zadavan u vrijednostima od $5 \%, 10 \%, 20 \%, 25 \%$, a pozitivni ekscentricitet nastao preklopom štapova, u vrijednostima od $5 \%, 10 \%, 20 \%$ i 30\%. Rešetkasti nosač je opterećen stalnim kontinuiranim opterećenjem vrijednosti $5.0 \mathrm{kN} / \mathrm{m}$ te korisnim kontinuiranim opterećenjem vrijednosti $2.5 \mathrm{kN} / \mathrm{m}$, koncentriranima u čvorove gornjeg pojasa. Rezultati su, radi lakše usporedbe, prikazani u obliku bezdimenzionalnih dijagrama, gdje se na osi ordinate nalaze vrijednosti faktora uzdužnih sila $f_{N}$, a na osi apcise naneseni su omjeri ekscentriciteta $\varepsilon$. Prema tome vrijedi:

$$
f_{N}=\frac{N_{e}}{N_{0}}, \varepsilon=\frac{e}{h_{0}}
$$

gdje je faktor uzdužnih sila omjer unutarnje uzdužne sile dobivene s ekscentricitetom $N_{e}$ i unutarnje uzdužne sile dobivene bez zadanog ekscentriciteta $N_{0}$. Omjer ekscentriciteta uzet je kao omjer skraćenja/produljenja duljine štapa ispune i visine presjeka pojasnog štapa.

\section{Statička analiza}

Kako je rečeno u uvodu, unaprijed je odabrana geometrija rešetkastog nosača, a prikazana je na slici 1 . U prvom koraku analizirana je rešetka s centrično spojenim štapovima, a nakon toga su zadavani ekscentriciteti u donjem, zatim u gornjem, te u oba pojasa. Slučajevi zadavanja pozitivnih i negativnih ekscentriciteta prikazani su na slici 2.
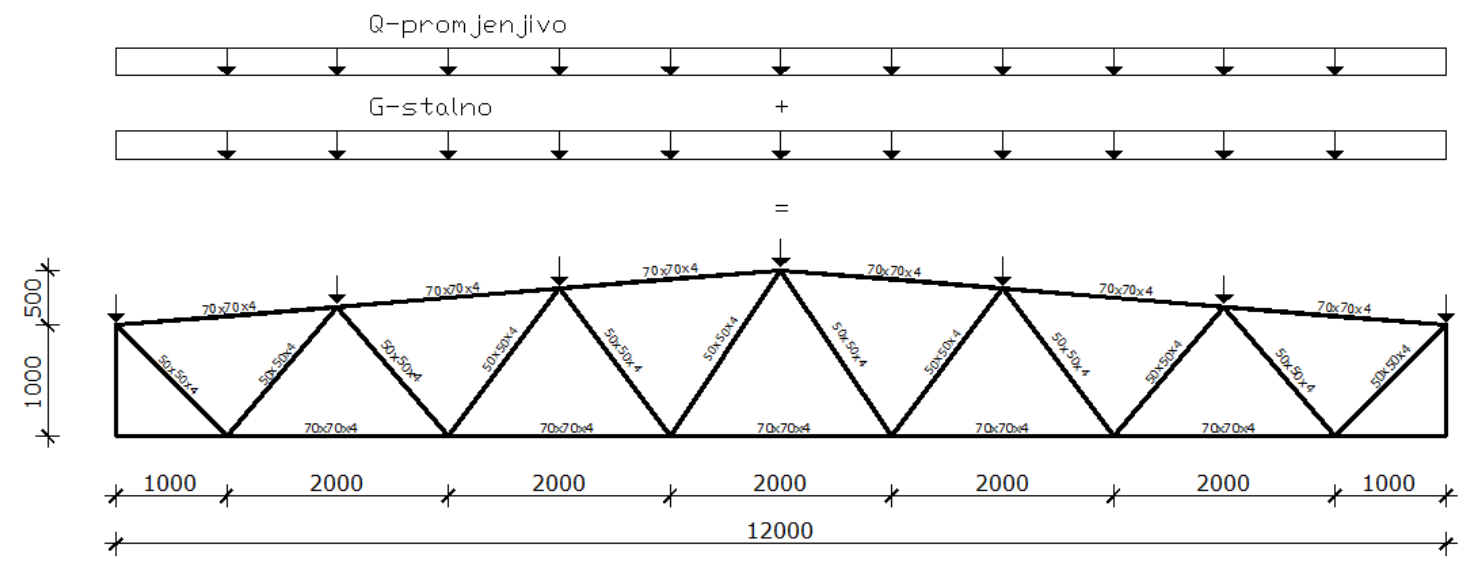

Slika 1 - Rešetkasta konstrukcija i opterećenje 


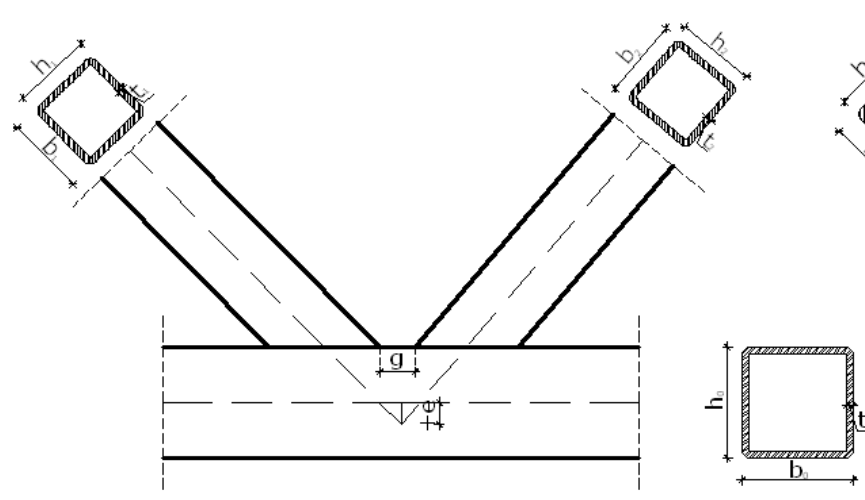

ekscentricitet izazvan razmakom-pozitivan ekscentricitet

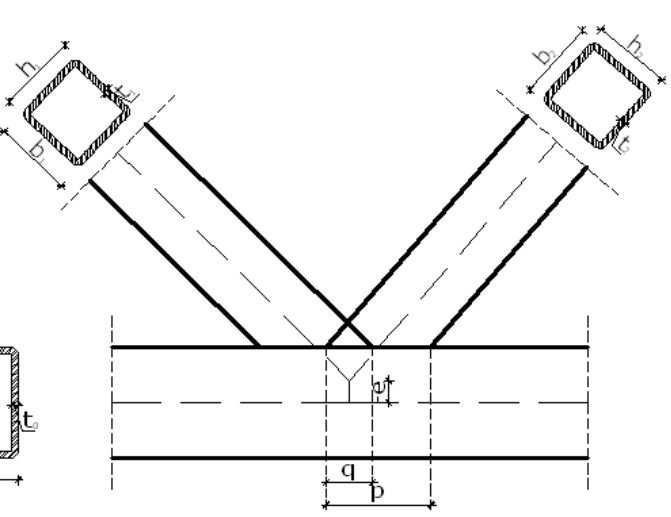

ekscentricitet izazvan preklopom-negativan ekscentricitet

\section{Slika 2 - Zadavanje negativnog i pozitivnog ekscentriciteta}

\section{Proračun nosivosti priključka prema euro normama}

Mogući načini otkazivanja nosivosti, na temelju kojih je proveden proračun priključka su: plastifikacija lica pojasnog štapa, posmični proboj stijenke pojasnog štapa tlačnim štapom, te otkazivanje štapa ispune zbog smanjenja efektivne širine pukotinom u zavaru ili štapu ispune. Potrebni izrazi za proračun nosivosti prema [1] su:

1) plastifikacija lica pojasnog štapa:

$$
N_{i, R d}=\frac{\frac{8,9 \cdot k_{n} \cdot f_{y 0} \cdot t_{0}{ }^{2} \cdot \sqrt{\gamma}}{\sin \theta_{i}} \cdot \beta}{\gamma_{M 5}}
$$

2) posmični proboj stijenke pojasnog štapa kao pojava pukotine ili odvajanje štapa ispune od pojasa:

$$
N_{i, R d}=\frac{f_{y i} \cdot t_{i} \cdot\left(2 \cdot h_{i}-4 \cdot t_{i}+b_{i}+b_{e f f}\right)}{\gamma_{M 5}}
$$

3) otkazivanje štapa ispune zbog smanjenja efektivne širine:

$$
\begin{aligned}
& N_{i, R d}=\frac{\frac{f_{y 0} \cdot t_{0}}{\sqrt{3} \cdot \sin \theta_{i}} \cdot\left(\frac{2 \cdot h_{i}}{\sin \theta_{i}}+b_{i}+b_{e, p}\right)}{\gamma_{M 5}} \\
& N_{i, R d}=\frac{f_{y i} \cdot t_{i} \cdot\left(b_{e f f}+b_{e, o v}+\frac{\lambda_{o v}}{50} \cdot\left(2 \cdot h_{i}-4 \cdot t_{i}\right)\right)}{\gamma_{M 5}}
\end{aligned}
$$


U izrazima 2, 3, 4 i 5 su: $\quad \theta_{1} \quad$ - kut između štapova ispune

$f_{y i} \quad$ - granica popuštanja za štap

$b_{i} \quad$ - ukupna širina šupljeg kutijastog profila

$b_{\text {eff }} \quad$ - efektivna širina spoja između štapa ispune i pojasnog štapa

$b_{e, o v} \quad$ - efektivna širina spoja između dva štapa kod preklopa

$b_{e, p} \quad$ - djelotvorna širina spoja pri posmičnom proboju stijenke profila

$t_{i} \quad$ - debljina stijenke šupljeg kutijastog profila

$\lambda_{\text {ov }} \quad$ - omjer preklopa u postotcima

$\beta \quad$ - omjer širine štapa ispune i širine pojasnog štapa $\mathrm{i}$

$\gamma \quad$ - omjer širine pojasnog štapa i dvostruke debljine stijenke.

U tablici 1 dan je pregledni prikaz rezultata dobivenih proračunom nosivosti prema [1] za centrično spojeni priključak te za sve tipove ekscentrično spojenog priključka. Rezultati su dani za najmanji postotak ekscentriciteta od $5 \%$ visine pojasnog presjeka.

Tablica 1 - Rezultati proračuna prema [1] za ekscentricitet u vrijednosti od 5\%

\begin{tabular}{|c|c|c|c|}
\hline \multicolumn{4}{|c|}{ VRIJEDNOSTI SILA IZAČUNATIH PO EURONORMAMA ZA CENTRIČNO SPOJENE ŠTAPOVE } \\
\hline Izraz & & Vlačna ispuna & Tlačna ispuna \\
\hline (5) & Centrično spojeni štapovi & \multicolumn{2}{|c|}{$72,32 \mathrm{kN}$} \\
\hline \multicolumn{4}{|c|}{ VRIJEDNOSTI SILA IZRAČUNATIH PO EURONORMAMA ZA EKSCENTRICITET OD 5\% } \\
\hline & Tipovi ekscentriciteta & Vlačna ispuna & Tlačna ispuna \\
\hline (5) & Pozitivan ekscentricitet na gornjem pojasu & \multicolumn{2}{|c|}{$72,620 \mathrm{kN}$} \\
\hline (2) & \multirow{3}{*}{ Pozitivan ekscentricitet na donjem pojasu } & $99,779 \mathrm{kN}$ & $92,975 \mathrm{kN}$ \\
\hline (3) & & \multicolumn{2}{|c|}{$152,816 \mathrm{kN}$} \\
\hline (4) & & $184,781 \mathrm{kN}$ & $165,307 \mathrm{kN}$ \\
\hline (2) & \multirow{3}{*}{ Pozitivan ekscentricitet na oba pojasa } & $99,606 \mathrm{kN}$ & $99,836 \mathrm{kN}$ \\
\hline (3) & & \multicolumn{2}{|c|}{$152,816 \mathrm{kN}$} \\
\hline (4) & & $184,274 \mathrm{kN}$ & $164,922 \mathrm{kN}$ \\
\hline (5) & Negativan ekscentricitet na gornjem pojasu & \multicolumn{2}{|c|}{$72,047 \mathrm{kN}$} \\
\hline (5) & Negativan ekscentricitet na donjem pojasu & \multicolumn{2}{|c|}{$87,662 \mathrm{kN}$} \\
\hline (5) & Negativan ekscentricitet na oba pojasa & \multicolumn{2}{|c|}{$87,416 \mathrm{kN}$} \\
\hline
\end{tabular}

Iz izračunatih nosivosti s minimalnim ekscentricitetom prema euronormama, vidi se da je najmanja vrijednost sile u štapovima ispune upravo zbog otkazivanja štapa ispune, te su stoga za preostale vrijednosti ekscentriciteta računane pripadne sile pomoću izraza 4 i 5 . Rezultati u obliku bezdimenzionalnih dijagrama prikazani su na slikama 3 i 4. 


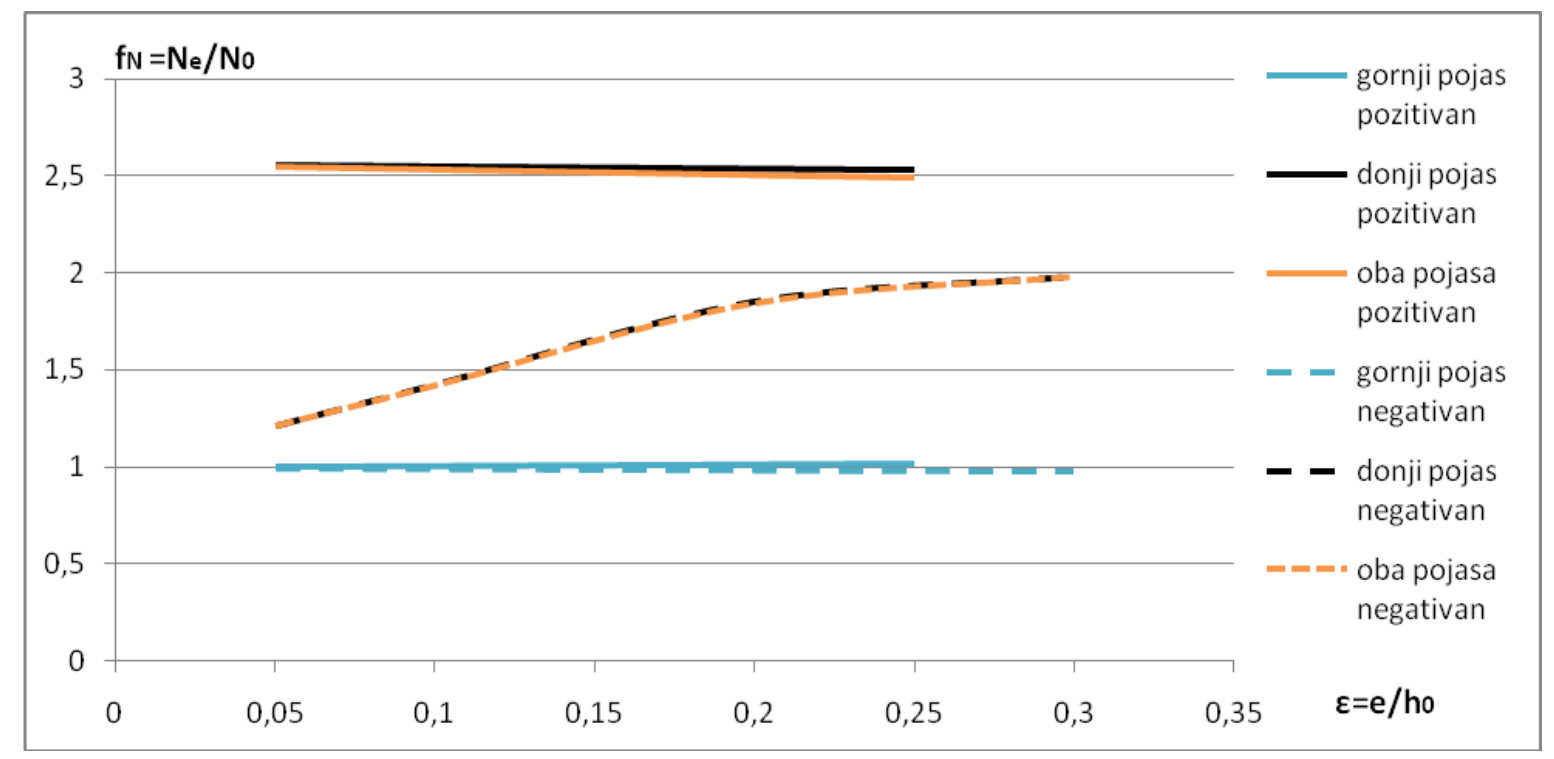

Slika 3 - Rezultati proračuna TLAČNE ispune dobiveni prema euronormama

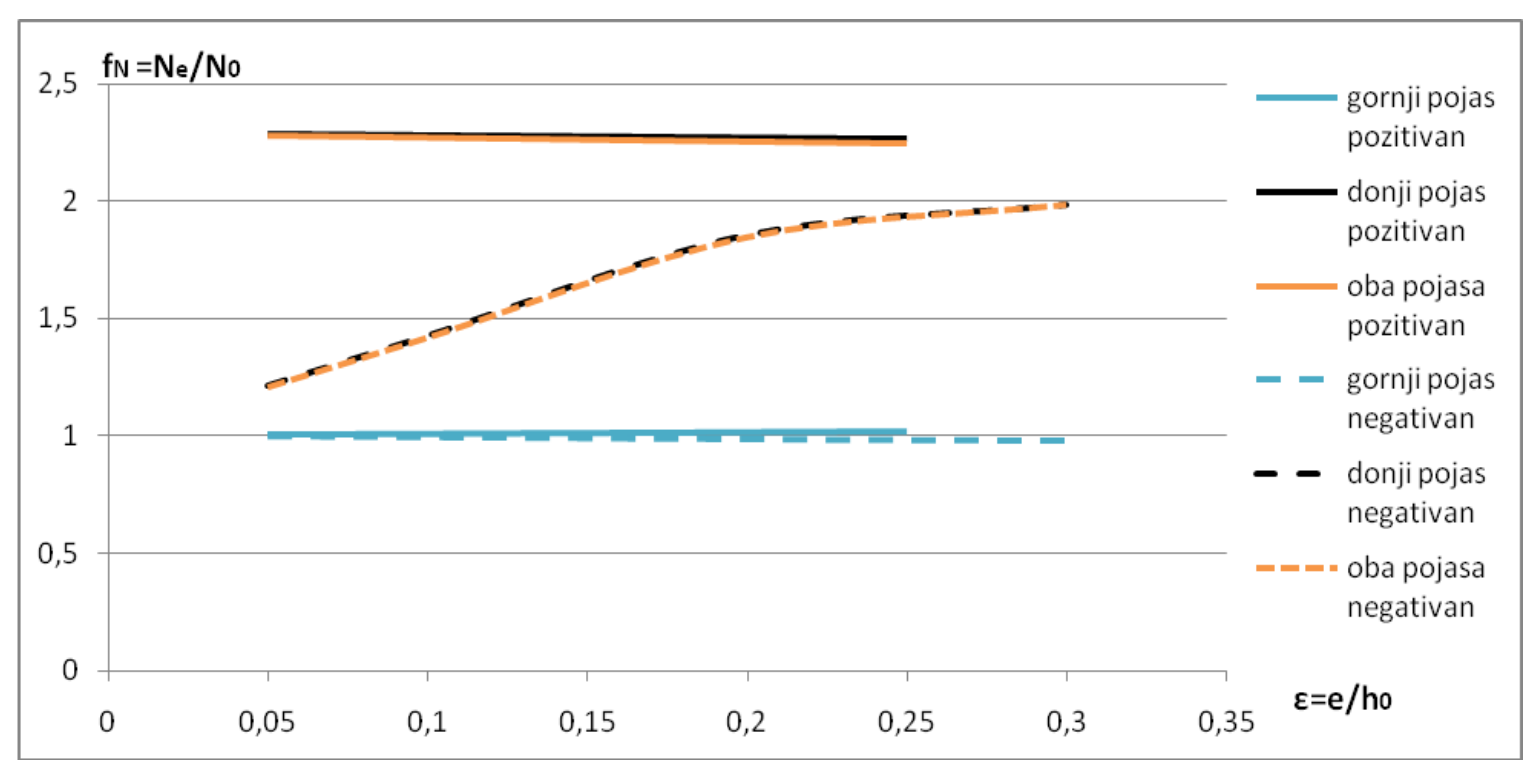

Slika 4 - Rezultati proračuna VLAČNE ispune dobiveni prema euronormama

\section{Proračun sila u štapovima priključka metodom KE}

Istovremeno su za zadano opterećenje i varijaciju ekscentriciteta dobivene najveće sile u vlačnom i tlačnom štapu ispune programskim paketom [7]. Očekivano su to sile u štapovima ispune prvog polja rešetke i iznose $70,19 \mathrm{kN}$ za tlačni, te $65,74 \mathrm{kN}$ za vlačni štap. Rezultati su prikazani bezdimenzionalnim dijagramima pomoću izraza 1 na slikama $5 \mathrm{i} 6$. 


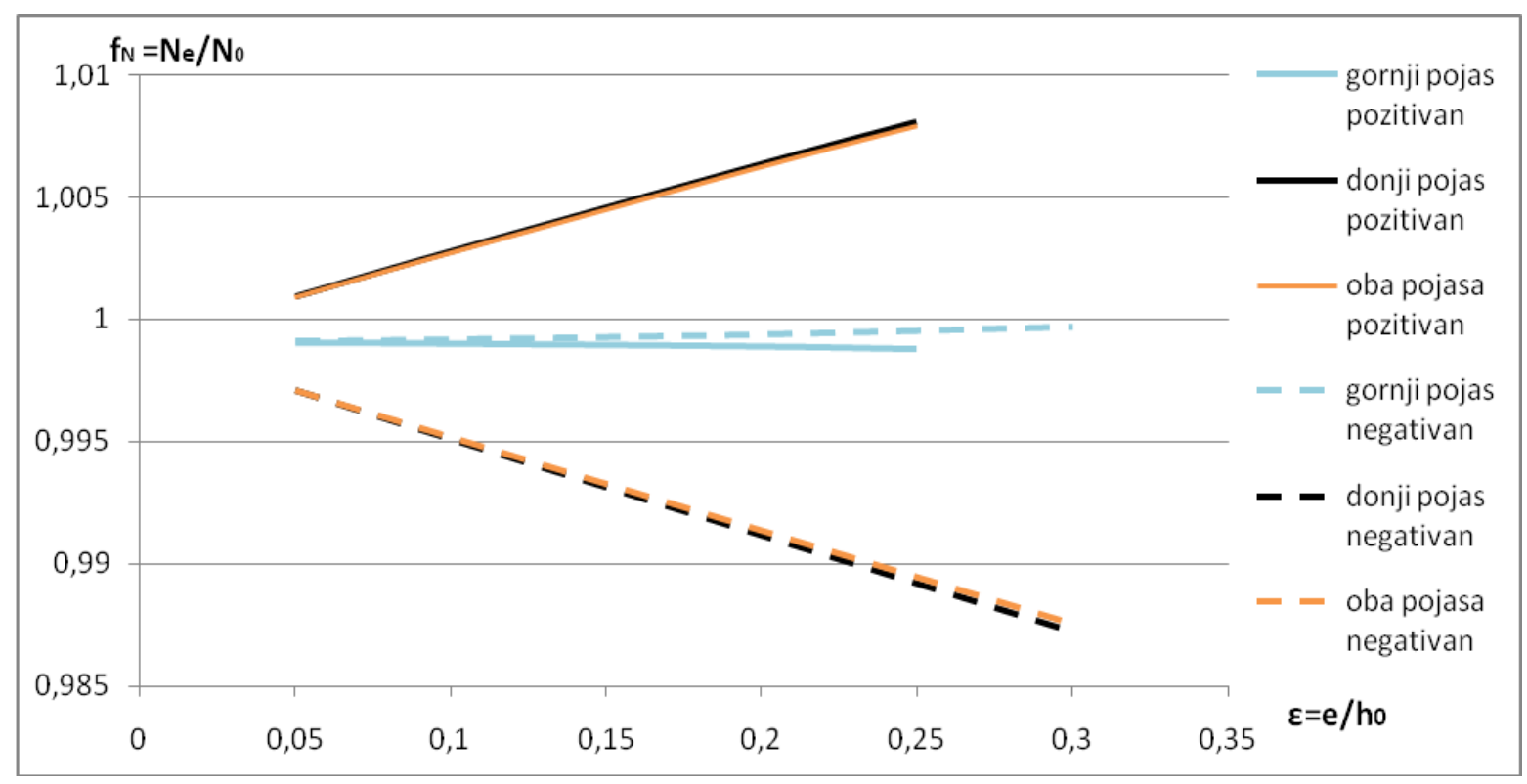

Slika 5 - Rezultati proračuna TLAČNE ispune dobiveni pomoću SAP2000 14 [2]

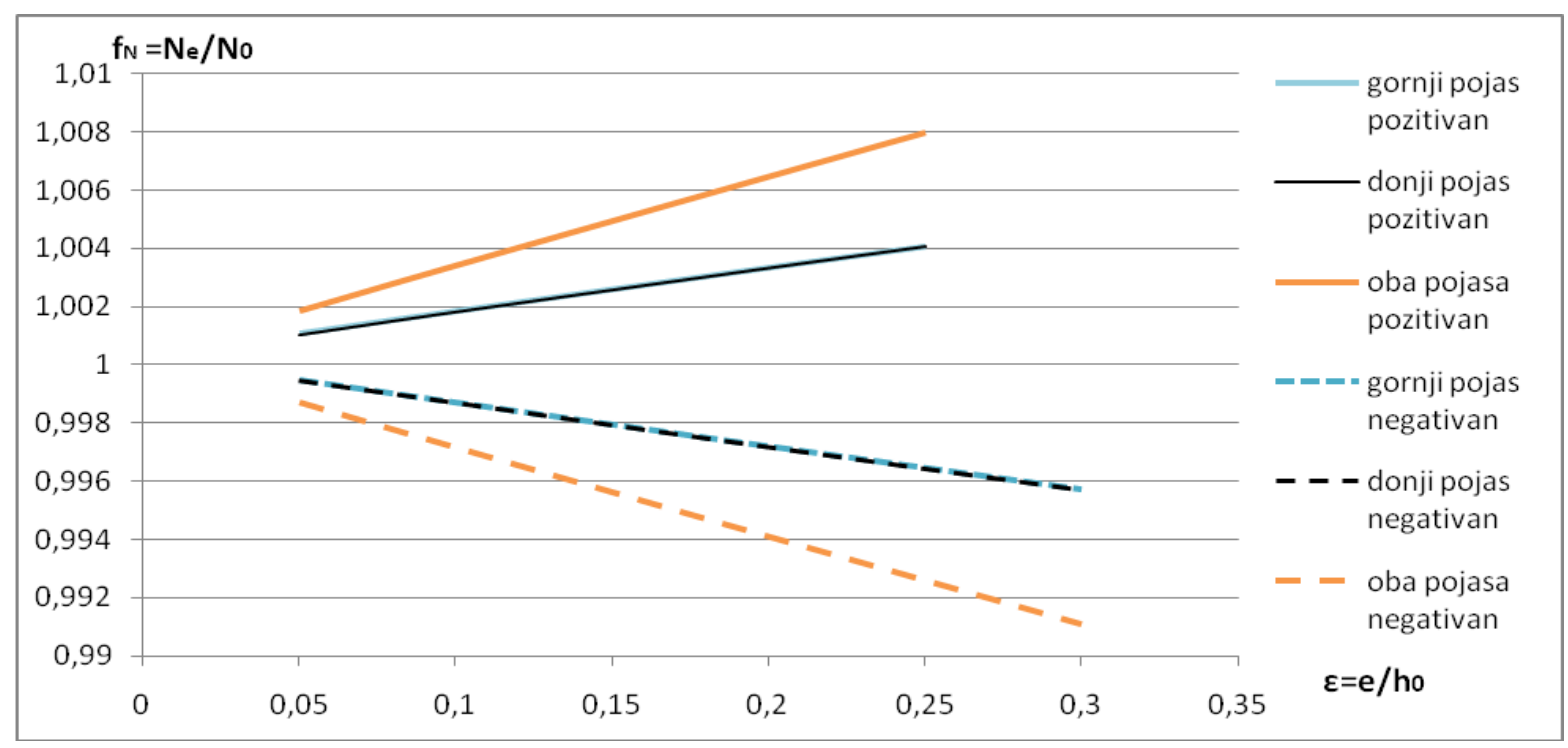

Slika 6 - Rezultati proračuna VLAČNE ispune dobiveni pomoću SAP2000 14 [2]

\section{Usporedba rezultata}

Kako bi se jednostavnije usporedile varijacije stvarnih sila i sila nosivosti prema euronormama, zavisno od promjene ekscentriciteta, uzeti su bezdimenzionalni rezultati za ekscentricitete u oba pojasa, a prikaz se vidi na slikama 7 i 8. 


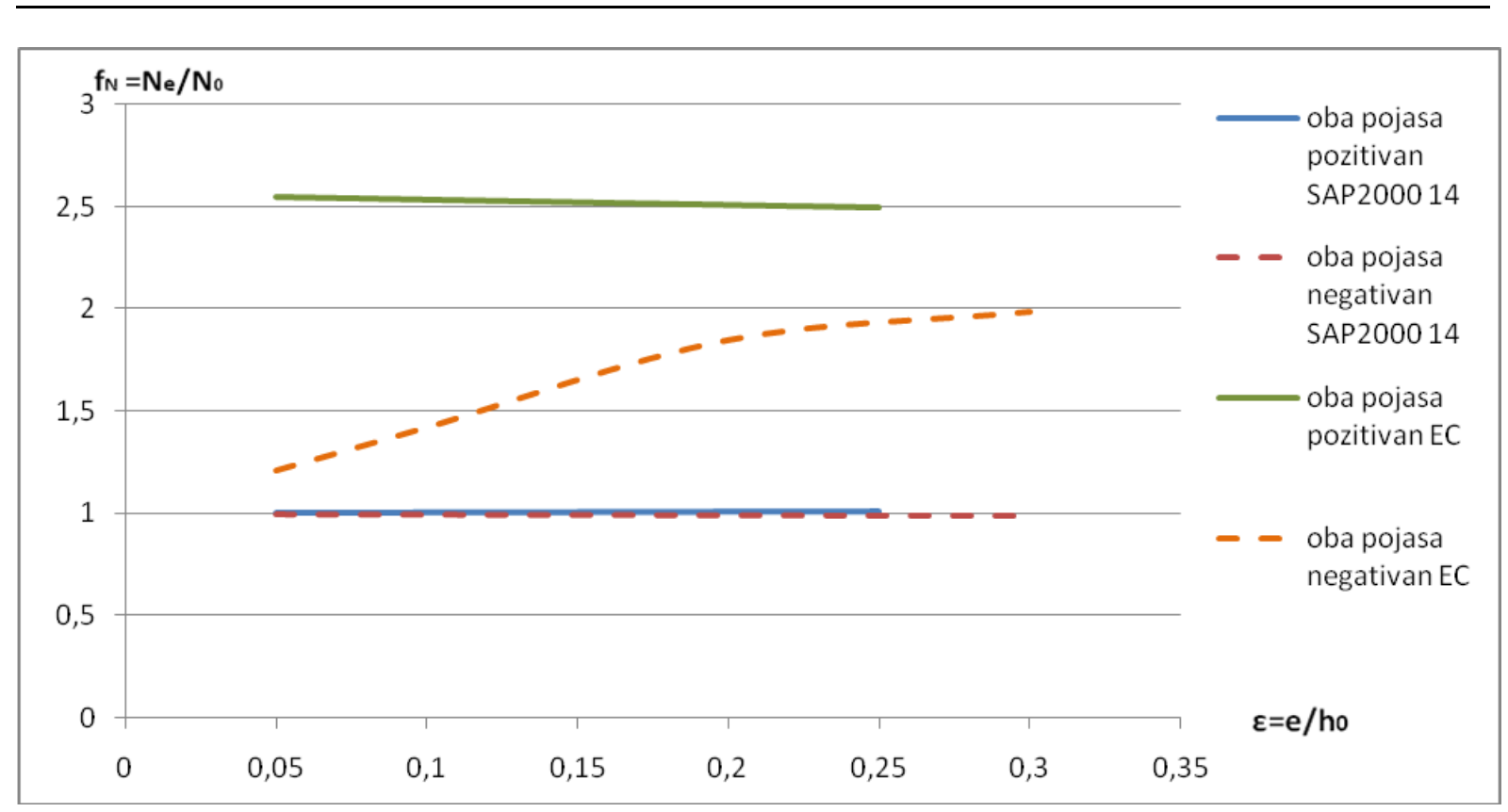

Slika 7 - Dijagrami za TLAČNU ispunu

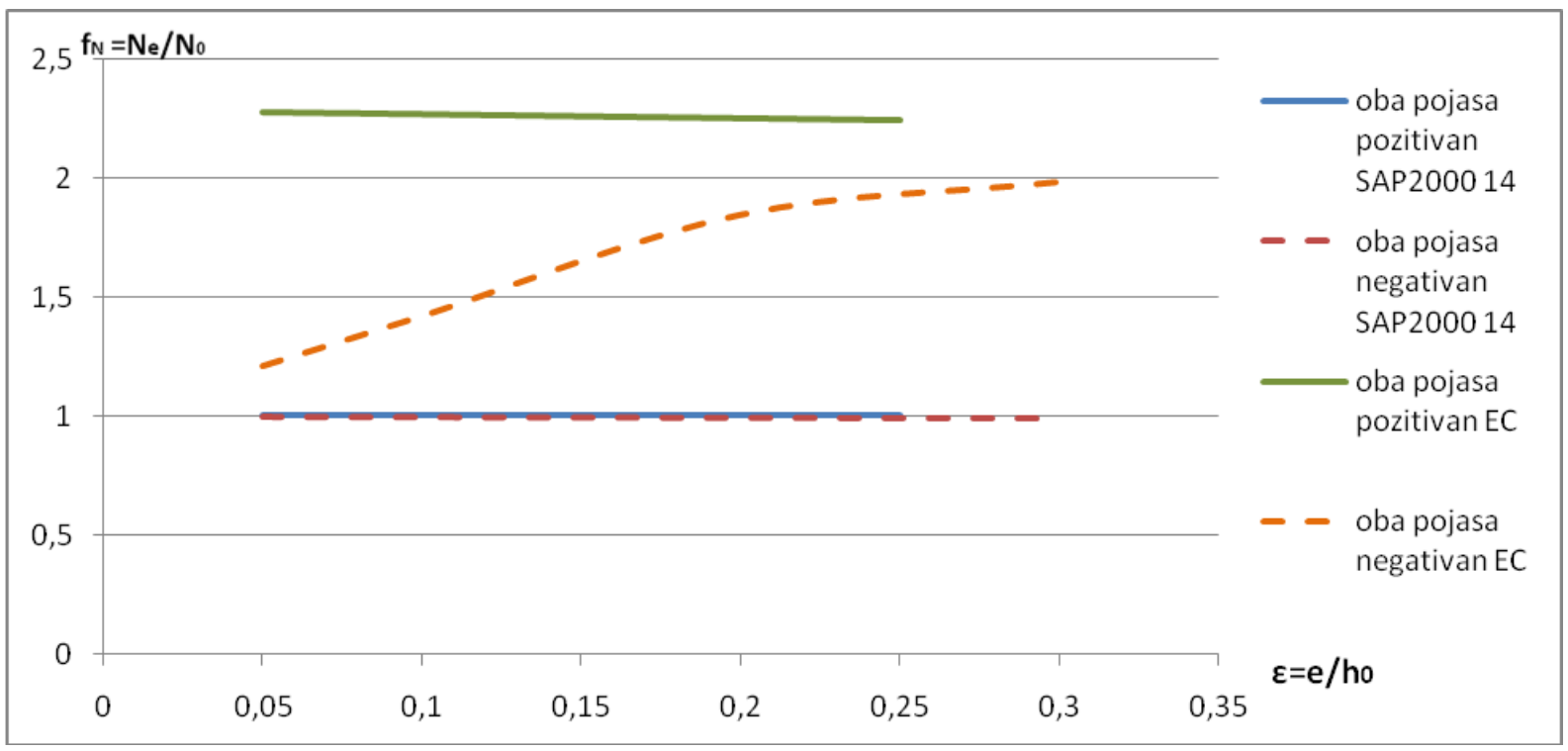

Slika 8 - Dijagrami za VLAČNU ispunu

\section{Zaključak}

Nakon provedene analize nosivosti priključka izrazima iz euronormi, može se zaključiti da povećanjem ekscentriciteta izazvanog razmakom između štapova u donjem kao i u oba pojasa, vrijednost uzdužne sile u obje ispune raste. $U$ slučaju ekscentriciteta izazvanog razmakom između štapova u gornjem, kao i ekscentriciteta izazvanog preklopom štapova u svim preostalim slučajevima, vrijednosti uzdužne sile u tlačnoj i vlačnoj ispuni opada. Provedenom analizom najvećih sila u štapovima ispune metodom KE, može se zaključiti da povećanjem ekscentriciteta izazvanog razmakom štapova u gornjem pojasu, vrijednost uzdužne sile u tlačnoj ispuni opada, dok vrijednost uzdužne sile u vlačnoj ispuni raste. $U$ donjem pojasu, kao i u slučaju ekscentriciteta istovremeno u oba pojasa, vrijednost uzdužne sile u tlačnoj i vlačnoj ispuni raste. Povećanjem ekscentriciteta izazvanog 
preklopom štapova u gornjem pojasu, vrijednost uzdužne sile u tlačnoj ispuni raste, dok u vlačnoj ispuni pada. U donjem pojasu, kao i u slučaju ekscentriciteta u oba pojasa, vrijednost uzdužne sile u tlačnoj i vlačnoj ispuni opada. Usporedbom rezultata za ekscentricitete u oba pojasa, sličnost pokazuju rezultati u slučaju pozitivnih ekscentriciteta, dakle ekscentriciteta izazvanih preklapanjem štapova.

Razmatrani rezultati upućuju na činjenicu koliko je važna precizna ugradnja štapova ispune pri izvedbi rešetke, posebno u slučajevima kada su ti štapovi u visokom stupnju iskorištenosti.

\section{Literatura}

[1] European Committe for Standardization (CEN) 2005: EN 1993-1-8, Eurocode 3: Design of steel structures Part 1-8: Design of Joints

[2] Džeba, I.; Androić, B.; Dujmović, D.: Metalne konstrukcije 3, I.A.P., Zagreb

[3] Markulak, D.: Proračun čeličnih konstrukcija prema EN 1993-1-1, Sveučilište J.J.Strossmayera u Osijeku, GF Osijek, 2008

[4] Knežević, I.; Mikolin, M.; Markulak, D.: Proračun priključaka u rešetkastim čeličnim nosačima prema Eurokod normama, e-GFOS (br.1)

[5] Radić, I.; Markulak, D.; Mikolin, M. 2010: Design and FEM Modelling of Steel Truss Girder Joints; Strojarstvo 52 (2) $125-135$

[6] Junušić, S., Anić, N., Jurić, A.: Utjecaj ekscentriciteta na unutarnje sile u rešetki

[7] Programski paket, 2009: CSI SAP2000 INTEGRATED SOFTWARE FOR STRUCTURAL ANALYSIS \& DESIGN V14. 